\section{Nutrient Density in Lettuce Cultivars Grown with Organic or Conventional Fertilization with Elevated Calcium Concentrations}

\author{
Md J. Meagy, Touria E. Eaton, and Allen V. Barker ${ }^{1}$ \\ Stockbridge School of Agriculture, University of Massachusetts, 201 Natural \\ Resources Road, Amherst, MA 01003
}

Additional index words. calcium accumulation, cultivar selection, fertilizer regimes, Lactuca sativa, lettuce genetics, lettuce phenotypes, macronutrients

\begin{abstract}
Calcium-rich vegetables in the diet could ameliorate the potential for calcium (Ca) deficiency in human nutrition. This study investigated the prospect of increasing $\mathrm{Ca}$ density of lettuce (Lactuca sativa $L$.) through cultivar selection and nutrient management in a greenhouse. Eighteen lettuce cultivars including butterhead, romaine, and loose-leaf phenotypes of heritage and modern genetics were tested. Organic fertilizer $(3 \mathrm{~N}-0.7 \mathrm{P}-$ 3.3K) and commercial conventional fertilizer $(20 \mathrm{~N}-4.4 \mathrm{P}-16.6 \mathrm{~K})$ factored with three $\mathrm{Ca}$ levels $\left(50,100,200 \mathrm{mg} \cdot \mathrm{L}^{-1}\right.$ as $\mathrm{CaCl}_{2}$ ) were the fertilizer regimes. Calcium in whole shoots was analyzed by atomic absorption spectrometry of oven-ashed samples. Heritage cultivars had a significantly higher Ca concentration $(1.93 \%$ dry weight) than modern cultivars $(1.54 \%)$. Loose-leaf phenotypes had the highest Ca concentration $(2.06 \%)$ followed by butterhead $(1.66 \%)$ and romaine $(1.49 \%)$. Accumulation of Ca was higher with the conventional fertilizer $(1.90 \%)$ than with the organic fertilizer $(1.58 \%)$. Elevated $\mathrm{Ca}$ level in the fertility regimes raised the $\mathrm{Ca}$ concentration in lettuce from $1.56 \%$ at $50 \mathrm{mg} \cdot \mathrm{L}^{-1}$ to a mean of $1.82 \%$ at $100 \mathrm{mg} \cdot \mathrm{L}^{-1}$ and $200 \mathrm{mg} \cdot \mathrm{L}^{-1}$. Large differences in $\mathrm{Ca}$ concentration occurred among individual cultivars with ranges from $1.27 \%$ to 3.05\%. 'Salad Bowl', 'Red Deer Tongue', 'Buttercrunch', and 'Bronze Mignonette' were the top in cultivar ranking with mean Ca concentration of $2.50 \%$, whereas 'Adriana', 'Australe', 'Coastal Star', and 'Forellenschluss' were low accumulators with a mean of $1.33 \%$. Head size of cultivars had no correlation with Ca concentration. This experiment indicates that selection of nutrient regimes and cultivars can be used to increase $\mathrm{Ca}$ accumulation in lettuce.
\end{abstract}

Critical functions in the human body require mineral nutrients that are obtained through consumption of food. Calcium is required for constructing and maintaining bones, clotting of blood, and for function of hormones and enzymes (Department of Health \& Human Services, 2000; Ervin et al., 2004; Karll, 2000; Krause and Mahan, 1984; National Research Council, 1989). Diets rich in Ca minimize Ca deficiency and maximize good health and well-being (Greenwald et al., 2001). The recommended daily intake of $\mathrm{Ca}$ for most men and women is $1000 \mathrm{mg} \cdot \mathrm{d}^{-1}$ (Meacham et al., 2008); however, for elderly individuals, the required $\mathrm{Ca}$ intake should total 1300 to $1700 \mathrm{mg} \cdot \mathrm{d}^{-1}$ (Heaney, 2001). A study suggested that it is possible to improve dietary $\mathrm{Ca}$

Received for publication 2 Aug. 2013. Accepted for publication 10 Oct. 2013.

This material is based on work supported by the National Institute of Food and Agriculture, U.S. Department of Agriculture, the Massachusetts Agricultural Experiment Station, and the Stockbridge School of Agriculture under Projects number MAS00963 and MAS00981. Paper number 3497 in the Experiment Station journal series.

${ }^{1}$ To whom reprint requests should be addressed; e-mail barker@umass.edu.
This study was conducted to determine whether the nutrient concentration of lettuce varied among cultivars and if nutritional regimes could be managed to increase the $\mathrm{Ca}$ contents in the produce. Brix was measured in this investigation to assess whether a correlation occurred between this reading and $\mathrm{Ca}$ concentration in lettuce.

\section{Materials and Methods}

Plant materials. Eighteen lettuce cultivars of heritage and modern genetics with butterhead, romaine, and loose-leaf phenotypes were studied. Seeds were obtained from Seeds of Change (Rancho Dominguez, CA) and Johnny's Seeds (Winslow, ME). All seeds were planted in peatmoss-based medium (Fafard Growing Mix 1-PV; Conrad Fafard Inc, Agawam, MA). Seedlings at the threeleaf stage were transplanted to $15-\mathrm{cm}$ round standard pots filled with the same peatmoss medium. Temperatures generally ranged from 23 to $30{ }^{\circ} \mathrm{C}$ during day and 18 to $24^{\circ} \mathrm{C}$ at night. Light conditions in the greenhouse, at the University of Massachusetts, Amherst (lat. $42.37^{\circ} \mathrm{N}$, long. $72.53^{\circ} \mathrm{W}$ ), were from sunlight during the season of production in June and July 2010 with $\approx 13 \mathrm{~h}$ of daylight and $11 \mathrm{~h}$ of night.

Treatments. Two fertilizers factored with three elevated $\mathrm{Ca}$ concentrations were fertility regimes for this study. One regime was conventional, peatlite professional fertilizer $(20 \mathrm{~N}-4.4 \mathrm{P}-16.6 \mathrm{~K}$ with micronutrients reported; Peters Fertilizer Products, J.R. Peters, Inc., Allentown, PA). The conventional fertilizer solution was prepared at $1 \mathrm{~g} \cdot \mathrm{L}^{-1}$ and $4 \mathrm{~mL} 0.5 \mathrm{M} \mathrm{MgSO}_{4}$ was added per liter. The second fertilizer regime was a commercial organic fertilizer $(3 \mathrm{~N}-0.7 \mathrm{P}-3.3 \mathrm{~K}$ with micronutrients not reported; Pure Blend Pro Grow; Pure Blend Pro Fertilizer Products, Chandler, AZ). The organic fertilizer solution was prepared at $6.7 \mathrm{~mL} \cdot \mathrm{L}^{-1}$ to approximate the supply from the conventional fertilizer. The factorial design consisted of three concentrations of $\mathrm{Ca}\left(50,100,200 \mathrm{mg} \cdot \mathrm{L}^{-1}\right.$ as $\left.\mathrm{CaCl}_{2}\right)$ with three replicates in randomized complete blocks. The two fertilizers solutions were applied at $100 \mathrm{~mL} /$ plant for the first week and then 200 $\mathrm{mL} /$ plant until harvest 3 weeks later. The nutrient solution drained through the medium during application to avoid salt accumulation in the medium and to ensure a constant supply of nutrients.

Measurements. At harvest, fresh weights of plants were recorded, and the samples were washed once in tap water and twice in deionized water and oven-dried to a constant weight at $70{ }^{\circ} \mathrm{C}$ with dry weights being recorded. For tissue analysis of $\mathrm{Ca}, 0.5 \mathrm{~g}$ of ground samples was ashed at $500{ }^{\circ} \mathrm{C}$ for $8 \mathrm{~h}$ in a furnace, and the ash was dissolved in $10 \%(\mathrm{v} / \mathrm{v}) \mathrm{HCl}$ prepared with distilled $\mathrm{H}_{2} \mathrm{O}$ and concentrated $\mathrm{HCl}$. The solutions were analyzed for $\mathrm{Ca}$ by atomic absorption spectrometry (Kalra, 1998).

Brix. Two leaves were selected from each head, one leaf from the center of the head and one from the outside. Juice was squeezed by hand into a plastic cup, mixed, and measured 
by a refractometer in sunlight (Pocket Refractometer PAL-1; ATAGO, Tokyo, Japan). One degree Brix is equivalent to $1 \mathrm{~g}$ of sucrose in $100 \mathrm{~mL}$ water. No correlation of Brix with $\mathrm{Ca}$ or other nutrient contents in plants is available.

Tipburn. Tipburn was assessed just before harvest by examination of each head of lettuce and ranking the severity of tipburn with an index of 0 , no tipburn; 1 , slight tipburn; 2 , moderate tipburn; and 3, severe tipburn based on judgment of the investigators.

Statistical analysis. The statistical analyses of data were performed by analysis of variance or regression analysis (Steel and Torrie, 1980) with data processing by SAS software (SAS Version 9.2; Cary, NC). Means were separated by Duncan's new multiple range test for main effects of treatments and by least significant difference for interactions of treatments (Steel and Torrie, 1980).

\section{Results}

Head weights. Fresh and dry weights of heads varied with cultivars (Table 1). The five largest headed cultivars had a mean fresh weight that was $40 \%$ larger and a mean dry weight that was $60 \%$ larger than the five smallest headed cultivars. 'Tropicana', 'Cosmo-Savoy', 'Buttercrunch', 'Coastal Star', 'Adriana', and 'Two Star' were grouped with high dry weights, and 'Tom Thumb', 'Winter Density', 'Black-Seeded Simpson', 'Bronze Mignonette', and 'Focea' had the lowest dry weights among the cultivars.

Table 1. Head weight of cultivars in descending order by fresh weight and listing of genetics and phenotypes of lettuce.

\begin{tabular}{llllr}
\hline & & & \multicolumn{2}{c}{${\left.\text { Head } \mathrm{wt}^{\mathrm{z}} \mathrm{g} / \mathrm{h} \text { head }\right)}$} \\
\cline { 5 - 5 } Cultivar & Genetics & Phenotype & Fresh & Dry \\
\hline Tropicana & Modern & Loose leaf & $177 \mathrm{a}$ & $11.6 \mathrm{ab}$ \\
Cosmo-Savoy & Heritage & Romaine & $175 \mathrm{ab}$ & $10.8 \mathrm{bc}$ \\
Buttercrunch & Heritage & Butterhead & $171 \mathrm{ab}$ & $11.5 \mathrm{ab}$ \\
Coastal Star & Modern & Romaine & $169 \mathrm{abc}$ & $12.0 \mathrm{a}$ \\
Adriana & Modern & Butterhead & $166 \mathrm{abc}$ & $11.4 \mathrm{ab}$ \\
Two Star & Modern & Loose leaf & $165 \mathrm{abcd}$ & $11.3 \mathrm{ab}$ \\
Forellenschluss & Heritage & Romaine & $162 \mathrm{abcde}$ & $9.6 \mathrm{de}$ \\
Claremont & Modern & Romaine & $158 \mathrm{abcde}$ & $9.0 \mathrm{ef}$ \\
Simpson Elite & Modern & Loose leaf & $156 \mathrm{bcde}$ & $9.1 \mathrm{ef}$ \\
Red Deer Tongue & Heritage & Loose leaf & $150 \mathrm{cde}$ & $7.1 \mathrm{gh}$ \\
Salad Bowl & Heritage & Loose leaf & $146 \mathrm{def}$ & $9.4 \mathrm{de}$ \\
Australe & Modern & Butterhead & $145 \mathrm{ef}$ & $9.1 \mathrm{ef}$ \\
Red Rosie & Modern & Romaine & $145 \mathrm{ef}$ & $10.1 \mathrm{~cd}$ \\
Focea & Modern & Butterhead & $145 \mathrm{ef}$ & $8.5 \mathrm{f}$ \\
Bronze Mignonette & Heritage & Butterhead & $143 \mathrm{ef}$ & $8.5 \mathrm{f}$ \\
Black-Seeded Simpson & Heritage & Loose leaf & $129 \mathrm{f}$ & $7.3 \mathrm{~g}$ \\
Winter Density & Heritage & Romaine & $112 \mathrm{~g}$ & $6.3 \mathrm{~h}$ \\
Tom Thumb & Heritage & Butterhead & $97 \mathrm{~g}$ & $4.9 \mathrm{i}$ \\
\hline
\end{tabular}

${ }^{\mathrm{z}}$ Means of cultivar fresh or dry weights with different letters in columns are significantly different by Duncan new multiple range test, $P=0.05$.

Heads of heritage (143 g/head) and modern $(158 \mathrm{~g})$ cultivars differed in fresh weights, and modern cultivars (10.2 $\mathrm{g} / \mathrm{head})$ also had higher dry weights than heritage cultivars $(8.4 \mathrm{~g})$ (Table 2). Loose-leaf phenotype had the highest fresh weight $(154 \mathrm{~g} /$ head $)$ followed by romaine $(153 \mathrm{~g})$ and butterhead $(145 \mathrm{~g})$ (Table 2). The dry weights of the phenotypic groups differed significantly in the same order as fresh weights. The organic and conventional regimes of fertilization had no significant effect on head weights (Table 2). Fresh and dry weights were slightly higher at $100 \mathrm{mg}$ $\mathrm{Ca} / \mathrm{L}$ than at 50 or $200 \mathrm{mg} \mathrm{Ca} / \mathrm{L}$ (Table 2); however, regression analysis showed no significant trend between head weights and $\mathrm{Ca}$ in the medium.

A significant interaction of genetic group and phenotype occurred for fresh weights and dry weights with modern cultivars of butterhead and loose-leaf phenotypes being larger than heritage cultivars, whereas romaine phenotypes of heritage cultivars were larger than modern cultivars (Table 3 ). The type of fertilizer and the interaction of fertilizer $x$ phenotype had no effect on head weights (Table 3). However, the levels of 100 or 200 $\mathrm{mg} \mathrm{Ca} / \mathrm{L}$ in the chemical fertilizer resulted in higher fresh or dry weights than the $50-\mathrm{mg}$ treatment (Tables 4 and 5). With the organic regime, $200 \mathrm{mg} \mathrm{Ca} / \mathrm{L}$ suppressed growth relative to the lower supplies of $\mathrm{Ca}$. The interaction of $\mathrm{Ca}$ level with phenotype or with genetic grouping (heritage or modern) was nonsignificant and is not reported.

Calcium concentration. Calcium concentrations varied widely among the cultivars ranging from $1.20 \%$ to $2.54 \%$ with organic fertilization and from $1.35 \%$ to $3.56 \%$ with conventional fertilization (Table 6). The interaction of fertilizer by variety was significant, although the ranking of cultivars did not differ within the fertilizers (Table 6). The $\mathrm{Ca}$

Table 2. Fresh weight, dry weights, calcium (Ca) concentration, total $\mathrm{Ca}$, and tipburn of lettuce heads as a function of modern or heritage genetics, butterhead, romaine, or loose-leaf phenotype, organic or conventional fertilization, and Ca supply of lettuce.

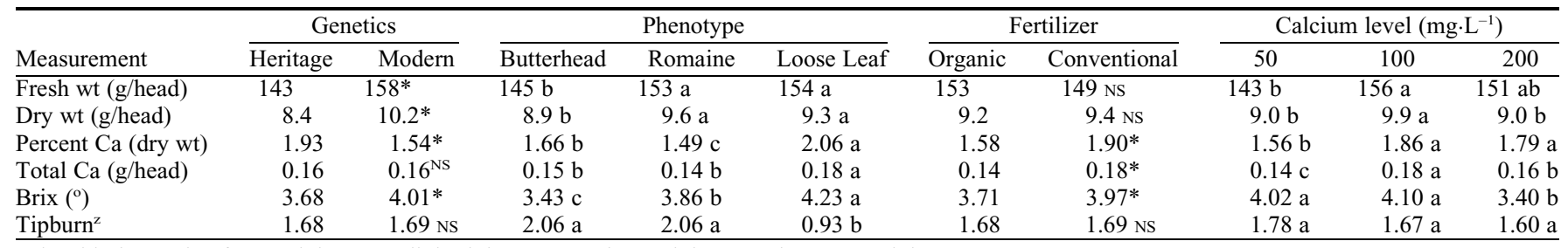

${ }^{\mathrm{z}}$ Visual index scale of 0 , no tipburn; 1, slight tipburn; 2, moderate tipburn; and 3, severe tipburn.

For genetics and fertilizers, Ns, *Means of measurements are not significantly different, $P>0.05$, or are significantly different by F-test, $P \leq 0.05$, respectively. For phenotypes and calcium levels, means followed by different letters are significantly different by Duncan's new multiple range test, $P=0.05$.

Table 3. Interaction of genetics and phenotypes and fertilizers on fresh weight of heads of lettuce.

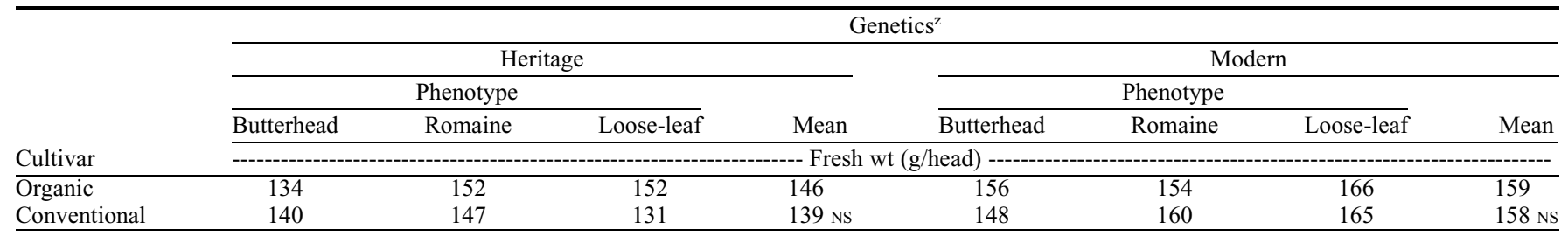

${ }^{\mathrm{z}}$ Least significant difference $(0.05)$ for interaction of fertilizers $\times$ genetics $\times$ phenotypes $=12$.

NS Means of fertilizers are not significantly different by F-test, $P>0.05$.

Means of phenotypes are reported in Table 2. 
Table 4. Interaction of type of fertilizer and calcium (Ca) level on fresh weight of lettuce listed in descending order of mean weights of cultivars.

\begin{tabular}{|c|c|c|c|c|c|c|c|c|c|}
\hline \multirow[b]{5}{*}{ Cultivar } & \multicolumn{8}{|c|}{ Type of fertilizer ${ }^{z}$} & \multirow[b]{4}{*}{ Cultivar mean } \\
\hline & \multicolumn{4}{|c|}{ Organic } & \multicolumn{4}{|c|}{ Conventional } & \\
\hline & \multicolumn{3}{|c|}{ Ca level } & \multirow[b]{2}{*}{ Mean } & \multicolumn{3}{|c|}{ Ca level } & \multirow[b]{2}{*}{ Mean } & \\
\hline & 50 & 100 & 200 & & 50 & 100 & 200 & & \\
\hline & \multicolumn{9}{|c|}{------------------------------------- Fresh wt (g/head) ------------------------------------ } \\
\hline Tropicana & 192 & 198 & 154 & 182 & 138 & 174 & 201 & 171 & $177 \mathrm{a}$ \\
\hline Cosmo-Savoy & 181 & 200 & 159 & 180 & 147 & 190 & 170 & 169 & $175 \mathrm{ab}$ \\
\hline Buttercrunch & 183 & 200 & 139 & 174 & 139 & 169 & 199 & 169 & $171 \mathrm{ab}$ \\
\hline Coastal Star & 162 & 172 & 166 & 167 & 135 & 179 & 199 & 171 & $169 \mathrm{abc}$ \\
\hline Adriana & 181 & 195 & 147 & 174 & 128 & 151 & 195 & 158 & $166 \mathrm{abc}$ \\
\hline Two Star & 179 & 160 & 159 & 166 & 146 & 155 & 191 & 164 & $165 \mathrm{abcd}$ \\
\hline Forellenschluss & 172 & 167 & 158 & 166 & 151 & 148 & 175 & 158 & 162 abcde \\
\hline Claremont & 175 & 153 & 136 & 154 & 151 & 170 & 163 & 161 & 158 abcde \\
\hline Simpson Elite & 162 & 163 & 130 & 152 & 126 & 160 & 195 & 160 & 156 bcde \\
\hline Red Deer Tongue & 162 & 162 & 146 & 157 & 146 & 132 & 149 & 142 & $150 \mathrm{cde}$ \\
\hline Salad Bowl & 168 & 188 & 123 & 160 & 123 & 121 & 154 & 133 & 146 def \\
\hline Australe & 151 & 172 & 129 & 150 & 131 & 149 & 141 & 140 & 145 ef \\
\hline Red Rosie & 144 & 158 & 121 & 141 & 123 & 158 & 166 & 149 & 145 ef \\
\hline Focea & 160 & 138 & 133 & 144 & 127 & 145 & 165 & 146 & 145 ef \\
\hline Bronze Mignonette & 121 & 166 & 116 & 135 & 132 & 153 & 171 & 152 & 143 ef \\
\hline Black-Seeded Simpson & 134 & 135 & 151 & 140 & 131 & 130 & 96 & 119 & $129 \mathrm{f}$ \\
\hline Winter Density & 127 & 110 & 97 & 111 & 92 & 117 & 128 & 112 & $112 \mathrm{~g}$ \\
\hline Tom Thumb & 79 & 92 & 114 & 95 & 77 & 108 & 111 & 99 & $97 \mathrm{~g}$ \\
\hline
\end{tabular}

${ }^{\mathrm{z}}$ Least significant difference $(0.05)$ for interaction of fertilizers $\times$ Ca level $\times$ cultivars $=12$.

${ }^{\mathrm{y}}$ Cultivar means followed with different letters are significantly different by Duncan's new multiple range test, $P=0.05$. These means are presented also in Table 1. Means of fertilizers calcium levels are reported in Table 2 .

Table 5. Fertilizers and calcium (Ca) level interaction with cultivars listed in descending order of mean dry weights of cultivars

\begin{tabular}{|c|c|c|c|c|c|c|c|c|c|}
\hline \multirow[b]{5}{*}{ Cultivar } & \multicolumn{8}{|c|}{ Type of fertilizer ${ }^{2}$} & \multirow[b]{4}{*}{ Cultivar mean ${ }^{\mathrm{y}}$} \\
\hline & \multicolumn{4}{|c|}{ Organic } & \multicolumn{4}{|c|}{ Conventional } & \\
\hline & \multicolumn{3}{|c|}{ Ca level } & \multirow[b]{2}{*}{ Mean } & \multicolumn{3}{|c|}{ Ca level } & \multirow[b]{2}{*}{ Mean } & \\
\hline & 50 & 100 & 200 & & 50 & 100 & 200 & & \\
\hline & $\overline{c----}$ & ------ & ----- & --------- & Dry $n$ & (g/hea & 1)----- & 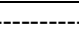 & ------------------- \\
\hline Coastal Star & 12.6 & 11.8 & 9.9 & 11.4 & 9.8 & 13.1 & 14.8 & 12.6 & $12.0 \mathrm{a}$ \\
\hline Tropicana & 13.1 & 13.1 & 9.1 & 11.8 & 8.6 & 12.7 & 13.1 & 11.5 & $11.6 \mathrm{a}$ \\
\hline Buttercrunch & 12.8 & 13.7 & 8.4 & 11.6 & 9.2 & 11.3 & 13.6 & 11.4 & $11.5 \mathrm{a}$ \\
\hline Adriana & 12.5 & 13.4 & 8.8 & 11.5 & 8.7 & 11.9 & 13.0 & 11.2 & $11.4 \mathrm{ab}$ \\
\hline Two Star & 12.3 & 10.9 & 10.4 & 11.2 & 9.8 & 11.6 & 13.1 & 11.5 & $11.3 \mathrm{ab}$ \\
\hline Cosmo-Savoy & 11.7 & 12.2 & 8.9 & 11.0 & 8.4 & 12.5 & 10.9 & 10.6 & $10.8 \mathrm{bc}$ \\
\hline Red Rosie & 10.4 & 11.1 & 8.0 & 9.8 & 8.2 & 11.6 & 11.5 & 10.4 & $10.1 \mathrm{~cd}$ \\
\hline Forellenschluss & 9.8 & 9.4 & 9.4 & 9.5 & 10.1 & 9.1 & 10.1 & 9.7 & $9.6 \mathrm{de}$ \\
\hline Salad Bowl & 10.9 & 10.7 & 7.1 & 9.6 & 7.8 & 9.5 & 10.3 & 9.2 & $9.4 \mathrm{de}$ \\
\hline Australe & 9.7 & 10.9 & 7.8 & 9.5 & 7.6 & 9.8 & 8.9 & 8.7 & $9.1 \mathrm{ef}$ \\
\hline Simpson Elite & 9.3 & 9.3 & 7.0 & 8.5 & 8.0 & 10.3 & 10.7 & 9.7 & $9.1 \mathrm{ef}$ \\
\hline Claremont & 10.4 & 9.1 & 7.2 & 9.9 & 8.3 & 9.7 & 9.1 & 9.0 & $9.0 \mathrm{ef}$ \\
\hline Bronze Mignonette & 7.1 & 9.3 & 6.3 & 7.5 & 8.1 & 9.9 & 10.6 & 9.5 & $8.5 \mathrm{f}$ \\
\hline Focea & 9.4 & 8.2 & 7.5 & 8.4 & 7.5 & 9.1 & 9.4 & 8.7 & $8.5 \mathrm{f}$ \\
\hline Black-Seeded Simpson & 7.3 & 7.6 & 8.1 & 7.6 & 7.8 & 7.4 & 5.4 & 6.9 & $7.3 \mathrm{~g}$ \\
\hline Red Deer Tongue & 7.4 & 7.2 & 7.0 & 7.2 & 7.1 & 6.6 & 6.8 & 6.8 & $7.0 \mathrm{gh}$ \\
\hline Winter Density & 7.4 & 6.6 & 5.2 & 6.4 & 5.0 & 7.1 & 6.8 & 6.3 & $6.3 \mathrm{~h}$ \\
\hline Tom Thumb & 4.5 & 4.7 & 3.9 & 4.4 & 4.1 & 5.6 & 6.4 & 5.4 & $4.9 \mathrm{i}$ \\
\hline
\end{tabular}

${ }^{\mathrm{z}}$ Least significant difference $(0.05)$ for interaction of fertilizers $\times$ Ca level $\times$ cultivar $=0.7$.

${ }^{y}$ Cultivar means followed with different letters are significantly different by Duncan's new multiple range test, $P=0.05$. These data are presented also in Table 1. Means for fertilizers and calcium levels are reported Tables 2 .

concentration was always higher with conventional fertilization but the elevation with conventional over organic fertilization ranged from $4 \%$ to $49 \%$ among cultivars. Mean $\mathrm{Ca}$ concentration was $\approx 20 \%$ higher with conventional fertilization $(1.90 \%)$ than with organic fertilization (1.58\%) (Tables 2 and 6). Heritage cultivars had $\approx 25 \%$ higher $\mathrm{Ca}$ concentration $(1.93 \%)$ than modern cultivars $(1.54 \%)$ (Table 2). Loose-leaf phenotypes had the highest $\mathrm{Ca}$ concentrations $(2.06 \%)$ followed by butterhead $(1.66 \%)$ and romaine $(1.49 \%)$ phenotypes (Table 2). The Ca concentrations with 100 or $200 \mathrm{mg} \mathrm{Ca} / \mathrm{L}$ (mean $1.82 \%$ ) were higher than that occurring at $50 \mathrm{mg} \mathrm{Ca} / \mathrm{L}$ (Table 2). The interaction of genetics with $\mathrm{Ca}$ level was significant (Table 7). Heritage cultivars were always higher in Ca than modern cultivars, but the difference ranged from $14 \%$ to $32 \%$. The interaction of cultivar with $\mathrm{Ca}$ level was significant with cultivars showing different trends in accumulation of $\mathrm{Ca}$ as $\mathrm{Ca}$ level increased (Table 8). Interactions other than fertilizer $\times$ cultivar, genetics $\times$ Ca level, and cultivar $\times \mathrm{Ca}$ level had no significant effect on $\mathrm{Ca}$ concentration and are not reported.

Total calcium accumulation. Total $\mathrm{Ca}$ accumulation among the cultivars varied from 0.07 to $0.28 \mathrm{~g} /$ head (Table 9). Cultivars with notably high accumulation were 'Salad Bowl', 'Buttercrunch', and 'Red Deer Tongue'. Cultivars with notably low accumulation were 'Tom Thumb', 'Winter Density', and 'Black-Seeded Simpson'. Total Ca did not differ among heritage and modern cultivars (Table 2), but loose-leaf ( $0.18 \mathrm{~g} /$ head $)$ had higher accumulation than butterhead or romaine (mean $0.14 \mathrm{~g} / \mathrm{head}$ ) phenotype (Table 2 ). Total Ca was higher with conventional fertilization $(0.18 \mathrm{~g} / \mathrm{head})$ than with organic fertilization $(0.14 \mathrm{~g} /$ head) (Table 2). Total Ca was highest at $100 \mathrm{mg} \mathrm{Ca} / \mathrm{L}(0.18 \mathrm{~g} /$ head $)$ followed by the $200-(0.16 \mathrm{~g})$ and $50-\mathrm{mg} \mathrm{Ca} / \mathrm{L}$ treatments $(0.14 \mathrm{~g})$ (Table 2$)$ in a quadratic trend. An interaction of genetics $\times$ Ca level was significant with heritage cultivars showing an increase in total $\mathrm{Ca}$ with each increase in $\mathrm{Ca}$ level and modern varieties showing highest $\mathrm{Ca}$ at $100 \mathrm{mg} \cdot \mathrm{L}^{-1}$ (Table 8). An interaction of cultivar $\times \mathrm{Ca}$ level was significant showing that cultivars ranged in responses to increasing Ca supply with an increase, no increase, or a peak in accumulation at $100 \mathrm{mg} \mathrm{Ca} / \mathrm{L}$ as $\mathrm{Ca}$ supply increased from 50 to $200 \mathrm{mg} \cdot \mathrm{L}^{-1}$ (Table 9).

Calcium accumulation and head size. Overall, Ca concentration did not differ with head dry weights of cultivars, averaging $1.74 \%$ (Fig. 1), but total $\mathrm{Ca}$ in the cultivars widely and significantly differed with increasing total dry weight of the cultivars and ranged from 0.07 to $0.28 \mathrm{~g} /$ head (Fig. 1).

Brix. Refractometer $\left({ }^{\circ}\right.$ Brix $)$ readings differed with cultivars (Table 10). 'Forellenschluss', 'Two Star', 'Salad Bowl', 'Adriana', and 'Costal Star' had ${ }^{\circ}$ Brix of 4.5 or higher, whereas 'Winter Density', 'Buttercrunch', and 'Tom Thumb' had 'Brix of $\approx 3.0$ or below. Heritage (3.84) and modern (4.01) cultivars differed in ${ }^{\circ}$ Brix (Table 2), and differences also occurred among phenotypes with loose-leaf (4.23) having the highest ${ }^{\circ}$ Brix followed by romaine (3.85) and butterhead (3.43) cultivars. The two fertilizer groups differed significantly with the conventional (3.97) fertilizer giving higher ${ }^{\circ}$ Brix than organic fertilizer (3.71) (Table 2). The levels of 50 or $100 \mathrm{mg} \mathrm{Ca} / \mathrm{L}(4.02$ and 4.10 , respectively) resulted in higher ${ }^{\circ} \mathrm{Brix}$ than $200 \mathrm{mg} \mathrm{Ca} / \mathrm{L} \mathrm{(3.40).} \mathrm{Interactions} \mathrm{were}$ nonsignificant or presented no responses to suggest that any of these interactions were important factors in affecting ${ }^{\circ}$ Brix in lettuce. Polynomial regression analysis showed no significant relationship of percent $\mathrm{Ca}$ and ${ }^{\circ}$ Brix.

Tipburn. Cultivars differed with expression of tipburn ranging from no tipburn to severe tipburn (Table 11). Heritage and modern cultivars did not differ in expression of tipburn (Table 2), but loose-leaf cultivars (rating 0.93) had a lower ranking of tipburn than butterhead or romaine phenotypes (each rating 2.06) (Table 2). Tipburn did not differ with treatments of conventional or organic fertilization (Table 2). No interactive effects 
Table 6. Interaction of cultivar and fertilizer on the calcium concentration in lettuce arranged in descending order of mean calcium concentration in the cultivars.

\begin{tabular}{|c|c|c|c|}
\hline \multirow[b]{3}{*}{ Cultivar } & \multicolumn{2}{|c|}{ Fertilizer $^{2}$} & \multirow[b]{2}{*}{ Cultivar mean ${ }^{y}$} \\
\hline & Organic & Conventional & \\
\hline & \multicolumn{3}{|c|}{ 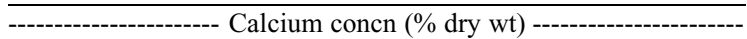 } \\
\hline Salad Bowl & 2.54 & 3.56 & $3.05 \mathrm{a}$ \\
\hline Red Deer Tongue & 2.53 & 3.51 & $3.02 \mathrm{a}$ \\
\hline Buttercrunch & 1.83 & 2.17 & $2.00 \mathrm{~b}$ \\
\hline Bronze Mignonette & 1.95 & 2.03 & $1.99 \mathrm{~b}$ \\
\hline Focea & 1.71 & 1.79 & $1.75 \mathrm{c}$ \\
\hline Simpson Elite & 1.52 & 1.97 & $1.73 \mathrm{~cd}$ \\
\hline Two Star & 1.39 & 1.84 & $1.61 \mathrm{cde}$ \\
\hline Winter Density & 1.44 & 1.76 & $1.60 \mathrm{cde}$ \\
\hline Red Rosie & 1.42 & 1.77 & $1.59 \mathrm{cdef}$ \\
\hline Claremont & 1.28 & 1.91 & $1.59 \mathrm{cdef}$ \\
\hline Cosmo-Savoy & 1.37 & 1.46 & $1.58 \mathrm{cdef}$ \\
\hline Tropicana & 1.38 & 1.66 & $1.52 \mathrm{def}$ \\
\hline Tom Thumb & 1.38 & 1.54 & $1.46 \mathrm{efg}$ \\
\hline Black-Seeded Simpson & 1.40 & 1.49 & $1.44 \mathrm{efg}$ \\
\hline Adriana & 1.22 & 1.54 & $1.38 \mathrm{fg}$ \\
\hline Australe & 1.31 & 1.45 & $1.38 \mathrm{fg}$ \\
\hline Coastal Star & 1.21 & 1.54 & $1.28 \mathrm{~g}$ \\
\hline Forellenschluss & 1.20 & 1.35 & $1.27 \mathrm{~g}$ \\
\hline
\end{tabular}

${ }^{2}$ Least significant difference $(0.05)$ for interaction is 0.31 .

${ }^{\mathrm{y}}$ Cultivar means followed by different letters are significantly different by Duncan's new multiple range test, $P=0.05$. Means of fertilizers are reported in Table 2 .

Table 7. Interaction of genetics with calcium (Ca) levels on calcium concentration and total $\mathrm{Ca}$ accumulation in lettuce.

\begin{tabular}{|c|c|c|}
\hline \multirow[b]{3}{*}{ Ca level $\left(\mathrm{mg} \cdot \mathrm{L}^{-1}\right)$} & \multicolumn{2}{|c|}{ Genetics $^{\mathrm{z}}$} \\
\hline & Heritage & Modern \\
\hline & \multicolumn{2}{|c|}{--- Ca concn $(\%$ dry wt)--- } \\
\hline 50 & 1.70 & 1.43 \\
\hline 100 & 2.05 & 1.66 \\
\hline \multirow[t]{2}{*}{200} & 2.06 & 1.52 \\
\hline & \multicolumn{2}{|c|}{----- Total Ca (g/head)----- } \\
\hline 50 & 0.14 & 0.14 \\
\hline 100 & 0.18 & 0.18 \\
\hline 200 & 0.17 & 0.15 \\
\hline
\end{tabular}

${ }^{\mathrm{z}}$ Least significant difference for $\mathrm{Ca}$ level $\times$ genetics interaction on percent $\mathrm{Ca}=0.13$ and on total $\mathrm{Ca}=$ 0.01. Means for main effects of $\mathrm{Ca}$ levels and modern and heritage cultivars are reported in Table 2 .

Table 8. Interaction of cultivar and calcium level on calcium $(\mathrm{Ca})$ concentration of lettuce.

\begin{tabular}{|c|c|c|c|}
\hline \multirow[b]{3}{*}{ Cultivar } & \multicolumn{3}{|c|}{$\mathrm{Ca} \mathrm{level}^{\mathrm{z}}$} \\
\hline & 50 & 100 & 200 \\
\hline & \multicolumn{3}{|c|}{-- Ca concn (\% dry wt) } \\
\hline Salad Bowl & 2.76 & 3.71 & 2.69 \\
\hline Red Deer Tongue & 2.47 & 3.22 & 3.36 \\
\hline Buttercrunch & 1.71 & 1.99 & 2.30 \\
\hline Bronze Mignonette & 1.57 & 1.90 & 2.50 \\
\hline Focea & 1.58 & 2.00 & 1.68 \\
\hline Simpson Elite & 1.69 & 1.91 & 1.58 \\
\hline Two Star & 1.76 & 1.74 & 1.35 \\
\hline Winter Density & 1.40 & 1.77 & 1.64 \\
\hline Red Rosie & 1.47 & 1.73 & 1.60 \\
\hline Claremont & 1.39 & 1.87 & 1.52 \\
\hline Cosmo-Savoy & 1.53 & 1.66 & 1.56 \\
\hline Tropicana & 1.38 & 1.48 & 1.71 \\
\hline Tom Thumb & 1.37 & 1.46 & 1.56 \\
\hline Black-Seeded Simpson & 1.32 & 1.48 & 1.53 \\
\hline Adriana & 1.24 & 1.64 & 1.27 \\
\hline Australe & 1.24 & 1.38 & 1.52 \\
\hline Coastal Star & 1.14 & 1.24 & 1.47 \\
\hline Forellenschluss & 1.19 & 1.25 & 1.39 \\
\hline
\end{tabular}

${ }^{\mathrm{z}}$ Least significant difference $(0.05)$ for interaction of cultivars $\times \mathrm{Ca}$ level $=0.39$.

Means of main effects of cultivars and levels of calcium are reported in Table 2 .
Table 9. Interaction of cultivar and calcium (Ca) level on total $\mathrm{Ca}$ accumulation by lettuce listed in order of descending accumulation.

\begin{tabular}{lllll}
\hline & \multicolumn{3}{c}{ Ca level } & Cultivar \\
\cline { 2 - 5 } & 50 & 100 & 200 & mean \\
\cline { 2 - 5 } Cultivar & $---------(\mathrm{g} \mathrm{Ca} /$ head $)$ & -------- \\
\hline Salad Bowl & 0.24 & 0.37 & 0.23 & $0.28 \mathrm{a}$ \\
Buttercrunch & 0.19 & 0.25 & 0.26 & $0.23 \mathrm{~b}$ \\
Red Deer Tongue & 0.18 & 0.22 & 0.23 & $0.21 \mathrm{~b}$ \\
Two Star & 0.19 & 0.19 & 0.16 & $0.18 \mathrm{c}$ \\
Tropicana & 0.15 & 0.19 & 0.20 & $0.18 \mathrm{c}$ \\
Cosmo-Savoy & 0.16 & 0.21 & 0.16 & $0.17 \mathrm{~cd}$ \\
Bronze Mignonette & 0.12 & 0.19 & 0.21 & $0.17 \mathrm{~cd}$ \\
Red Rosie & 0.13 & 0.20 & 0.16 & $0.16 \mathrm{~cd}$ \\
Simpson Elite & 0.15 & 0.19 & 0.14 & $0.16 \mathrm{~cd}$ \\
Adriana & 0.13 & 0.21 & 0.14 & $0.16 \mathrm{~cd}$ \\
Coastal Star & 0.13 & 0.15 & 0.18 & $0.15 \mathrm{~cd}$ \\
Focea & 0.14 & 0.18 & 0.14 & $0.15 \mathrm{de}$ \\
Claremont & 0.14 & 0.18 & 0.13 & $0.15 \mathrm{def}$ \\
Australe & 0.11 & 0.15 & 0.13 & $0.13 \mathrm{efg}$ \\
Forellenschluss & 0.12 & 0.12 & 0.14 & $0.12 \mathrm{fg}$ \\
Black-Seeded & 0.10 & 0.11 & 0.10 & $0.10 \mathrm{~g}$ \\
$\quad$ Simpson & & & & \\
Winter Density & 0.09 & 0.13 & 0.10 & $0.10 \mathrm{~g}$ \\
Tom Thumb & 0.06 & 0.08 & 0.09 & $0.07 \mathrm{~h}$ \\
\hline Least signifcant & & &
\end{tabular}

${ }^{\mathrm{z}}$ Least significant difference $(0.05)$ for interaction of cultivar $\times \mathrm{Ca}$ level $=0.05$.

${ }^{\mathrm{y}}$ Means followed by different letters for cultivars in column and fertilizers in row are significantly different by Duncan's new multiple range test, $P=0.05$. Means for $\mathrm{Ca}$ level are reported in Table 2.

were significant. The relationship between percent $\mathrm{Ca}$ in heads and expression of tipburn was nonsignificant by regression analysis.

\section{Discussion}

Modern cultivars had higher fresh weights than heritage cultivars because of genetic improvement in head sizes. Because of their smaller head sizes, heritage cultivars often are perceived to have higher mineral nutrient contents than modern cultivars (Mou, 2005, 2009). However, results of this investigation showed that $\mathrm{Ca}$ concentration did not differ overall with head size although total accumulation $(\mathrm{g} / \mathrm{head})$ varied, increasing as dry weight increased. Loose-leaf and romaine phenotypes had greater fresh weights than butterhead. Head weights did not differ in response to organic or chemical nutritional regimes. An increase in Ca nutrition from 50 to $200 \mathrm{mg} \cdot \mathrm{L}^{-1}$ increased head size in the chemical regime but had little effect in the organic regime. Loose-leaf cultivars Tropicana, Cosmo Savoy, Buttercrunch, Coastal Star, and Two Star had greater fresh weights than other cultivars. This difference in growth has been attributed to differences in transpiration and the resulting nutrient accumulation (Mou, 2009). Perhaps, loose-leaf and romaine phenotypes because of their morphology transpired more water than butterhead and therefore had increased nutrient uptake transport and higher growth.

The nutritional value of the lettuce cultivars differed with phenotypes. Loose-leaf lettuce cultivars contained higher $\mathrm{Ca}$ concentration and total $\mathrm{Ca}$ than butterhead or romaine types. Transpiration affects the delivery and distribution of $\mathrm{Ca}$ to lettuce leaves because young leaves of the developing heads can develop tipburn because the outer leaves are transpiring more than the young leaves, thereby depriving the young leaves of $\mathrm{Ca}$ (Collier and Tibbitts, 1982, 1984). Looseleaf cultivars had less tipburn than romaine or butterhead phenotypes, again suggesting differences in delivery of $\mathrm{Ca}$ to the young leaves by transpiration (Hylmö, 1953)

A great variation occurred for $\mathrm{Ca}$ accumulation among cultivars. Loose leaf cultivars Salad Bowl and Red Deer Tongue had the highest $\mathrm{Ca}$ concentrations. Butterhead cultivars Buttercrunch and Bronze Mignonette had high $\mathrm{Ca}$ concentrations. The semiopen head of 'Buttercrunch' and 'Bronze Mignonette' perhaps allows transpiration of water into the head and contributed to their higher $\mathrm{Ca}$ concentrations. In contrast, 'Winter Density', 'Red Rosie', and 'Cosmo-Savoy' accumulated moderate levels of $\mathrm{Ca}$ concentration within romaine types. The thick and semiopen leaves of romaine heads possibly obstruct the transpiration of water, thereby leading to lower Ca concentration than with loose-leaf and butterhead cultivars (Collier and Tibbitts, 1984). Butterhead cultivars Adriana and Australe and romaine cultivars Coastal Star and Forellenschluss had much lower $\mathrm{Ca}$ concentrations than other romaine and butterhead cultivars. 'Adriana', 'Australe', 'Coastal Star', and 'Forellenschluss' have partially closed heads, whereas others in romaine and butterhead phenotypes have open heads. The closed head perhaps obstructs the transpiration of water, resulting in lower $\mathrm{Ca}$ concentration in the leaves (Barta and Tibbitts, 1991).

Tipburn varied among the phenotypes and cultivars. Loose-leaf phenotypes expressed a lesser index of tipburn than romaine or butterhead structures. 'Forellenschluss', a heritage, romaine phenotype, expressed the highest tipburn index, whereas 'Salad Bowl' and 'Tropicana', heritage and modern loose leaf cultivars, respectively, had the lowest symptoms. 

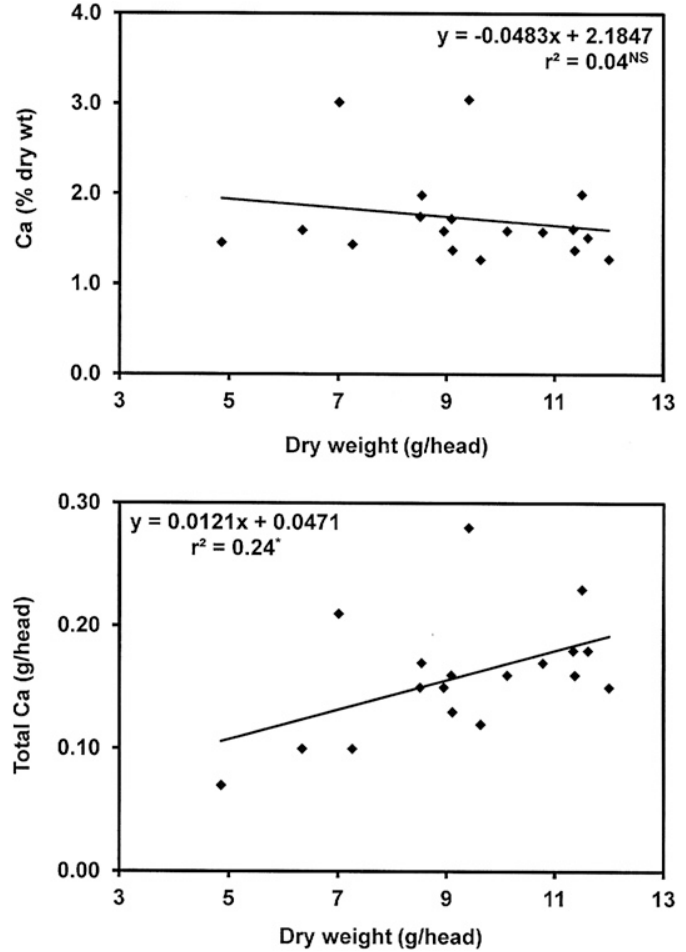

Fig. 1. Calcium concentration (top) and accumulation total calcium (Ca) (bottom) as a function of head dry weights of lettuce. Equations are linear regression models. Calcium concentration did not vary with dry weights, whereas total accumulation of $\mathrm{Ca}$ increased as dry weight increased.

Table 10. Refractometer readings among cultivars with ranking from highest to lowest ${ }^{\circ} \mathrm{Brix}$.

\begin{tabular}{llllll}
\hline & \multicolumn{5}{c}{ Refractometer reading ${ }^{\mathrm{z}}\left({ }^{\circ}\right.$ Brix $)$} \\
\hline Forellenschluss & $4.76 \mathrm{a}$ & Tropicana & $4.16 \mathrm{bcd}$ & Cosmo-Savoy & $3.58 \mathrm{f}$ \\
Two Star & $4.68 \mathrm{a}$ & Simpson Elite & $4.03 \mathrm{cde}$ & Australe & $3.57 \mathrm{f}$ \\
Salad Bowl & $4.51 \mathrm{ab}$ & Black-Seeded Simpson & $3.77 \mathrm{def}$ & Focea & $3.34 \mathrm{fg}$ \\
Adriana & $4.50 \mathrm{ab}$ & Bronze Mignonette & $3.67 \mathrm{ef}$ & Winter Density & $3.03 \mathrm{~g}$ \\
Coastal Star & $4.50 \mathrm{ab}$ & Red Rosie & $3.65 \mathrm{ef}$ & Buttercrunch & $2.98 \mathrm{~g}$ \\
Red Deer Tongue & $4.23 \mathrm{bc}$ & Claremont & $3.64 \mathrm{ef}$ & Tom Thumb & $2.54 \mathrm{~h}$ \\
\hline
\end{tabular}

${ }^{20}$ Brix followed by different letters are significantly different by Duncan's new multiple range test $(P=$ $0.05)$.

Table 11. Expression of tipburn among cultivars with ranking from highest to lowest symptoms.

\begin{tabular}{llllll}
\hline \multicolumn{5}{c}{ Cultivar and tipburn rating, 0 to 3 scale } \\
\hline Forellenschluss & $3.00 \mathrm{a}^{\mathrm{y}}$ & Adriana & $2.17 \mathrm{bcd}$ & Simpson Elite & $1.25 \mathrm{fg}$ \\
Red Deer Tongue & $2.75 \mathrm{a}$ & Claremont & $2.17 \mathrm{bcd}$ & Buttercrunch & $1.08 \mathrm{~g}$ \\
Focea & $2.67 \mathrm{ab}$ & Red Rosie & $1.92 \mathrm{cde}$ & Coastal Star & $0.83 \mathrm{~g}$ \\
Winter Density & $2.58 \mathrm{ab}$ & Cosmo-Savoy & $1.83 \mathrm{cdef}$ & Two Star & $0.17 \mathrm{~h}$ \\
Tom Thumb & $2.42 \mathrm{abc}$ & Bronze Mignonette & $1.75 \mathrm{def}$ & Salad Bowl & $0.08 \mathrm{~h}$ \\
Australe & $2.25 \mathrm{bcd}$ & Black-Seeded Simpson & $1.33 \mathrm{efg}$ & Tropicana & $0.00 \mathrm{~h}$ \\
\hline
\end{tabular}

${ }^{\mathrm{z}}$ Visual index of 0 , no tipburn; 1, slight tipburn; 2, moderate tipburn; 3, severe tipburn.

yTipburn ratings followed by different letters are significantly different by Duncan's new multiple range test $(P=0.05)$.

Calcium concentration in the whole heads was not related to severity of tipburn. This lack of relationship is because total $\mathrm{Ca}$ in the entire head was determined rather that Ca being determined in the affected leaves only.

Concentration of Ca did not vary with head weight, but total $\mathrm{Ca}$ accumulation increased with head weight. These results are important because they demonstrate that a dilution of $\mathrm{Ca}$ does not occur with an increase in dry mass and that consumers will receive the same amount of $\mathrm{Ca}$ from servings of lettuce regardless of head weight.
Deer Tongue', 'Buttercrunch', and 'Bronze Mignonette' ranking in the top among all cultivars in $\mathrm{Ca}$ concentration. A wide range of variability in Ca concentration occurred among different cultivars of lettuce including differing phenotypes and introductions. Therefore, improvement of nutrient density with lettuce through breeding and selection is a potentiality. Enhancing the mineral nutrition levels of lettuce would improve the nutrient uptake without requiring an increase in produce consumption.

\section{Literature Cited}

Anderson, A. 2009. Farming for health. Food quality, nutrient density \& crop Brix. Acres USA 17 July 2013. <http://www.acresusa.com/toolbox/ reprints/July09_Andersen.pdf>.

Ashkar, S.A. and S.K. Ries. 1970. Lettuce tipburn as related to nutrient imbalance and nitrogen composition. Michigan State University, East Lansing, MI.

Ashmead, H. 1982. Chelated mineral nutrition in plants, animals and man. Charles C. Thomas, Springfield, IL.

Barta, D.J. and T.W. Tibbitts. 1991. Calcium localization in lettuce leaves with and without tipburn: Comparison of controlled-environment and field-grown plants. J. Amer. Soc. Hort. Sci. 116:870-875

Bernstein, M.A., M.E. Nelson, K.L. Tucker, J. Layne, E. Johnson, A. Nuernberger, C. Castaneda, J.O. Judge, D. Buchner, and M.F. Singh. 2002. A home-based nutrition intervention to increase consumption of fruits, vegetables, and calciumrich foods in community dwelling elders. J. Amer. Diet. Assoc. 102:1421-1427.

Collier, G.F. and T.W. Tibbitts. 1982. Tipburn of lettuce. Hort. Rev. 4:49-65.

Collier, G.F. and T.W. Tibbitts. 1984. Effects of relative humidity and root temperature on calcium concentration and tipburn development in lettuce. J. Amer. Soc. Hort. Sci. 109:128.

Department of Health \& Human Services. 2000 Healthy People 2010: Objectives for improving health (Part B: Focus Areas 15-28). Vol. II. U.S. Government Printing Office, Washington, DC.

Ervin, R.B., C.-Y. Wang, J.D. Wright, and J. Kennedy-Stephenson. 2004. Dietary intake of selected minerals for the United States population: 1999-2000. Advance data from vital and health statistics. Vol. no. 341. National Center for Health Statistics, Hyattsville, MD.

Frank, J. 2013. Quest for nutrient density. 17 July 2013. <http://www.highbrixgardens.com/foods/ quest.html $>$.

Greenwald, P., C.K. Clifford, and J.A. Milner. 2001. Diet and cancer prevention. Eur. J. Cancer 37:948-965.

Hale, T.A., T. Phillips, and R.L. Hassell. 2005. Refractometer measurements of soluble solid concentration do not reliably predict sugar content in sweet corn. HortTechnology 15: 668-672.

Heritage cultivars accumulated higher $\mathrm{Ca}$ concentration but were not superior in accumulation of total $\mathrm{Ca}$ from modern cultivars resulting from modern cultivars having larger head weights. Loose-leaf cultivars accumulated higher $\mathrm{Ca}$ than romaine or butterhead phenotypes. Loose-leaf cultivars also had larger head fresh weights. Accumulation of $\mathrm{Ca}$ concentration or total $\mathrm{Ca}$ was higher in the chemical regime than in the organic regime. Cultivars differed widely in $\mathrm{Ca}$ accumulation with 'Salad Bowl', 'Red
Heaney, R.P. 2001. Calcium needs of the elderly to reduce fracture risk. J. Amer. Coll. Nutr. 20:192197.

Hylmö, B. 1953. Transpiration and ion absorption. Physiol. Plant. 6:333-405.

Ikeda, H., K. Kanahama, Y. Kanayama, M. Nishiyama, M. Hiraga, and K. Shirasawa. 2013. Analysis of a tomato introgression line, IL8-3, with increased brix content. Sci. Hort. 153:103-108.

Kalra, Y.P. 1998. Handbook of reference methods for plant analysis. CRC Press, Boca Raton, FL. 
Kamchan, A., P. Puwastien, P.P. Sirichakwal, and R. Kongkachuichai. 2004. In vitro calcium bioavailability of vegetables, legumes and seeds. J. Food Compost. Anal. 17:311-320.

Karll, E. 2000. Calcium and vitamin D, p. 173-181. In: Singh, M.A.F. (ed.). Exercise, nutrition, and the older woman: Wellness for women over fifty. CRC Press, Washington, DC.

Keat, C., L. Meng-Wei, and C. Ling. 1999. Effects of nutrient composition on butterhead lettuce (Lactuca sativa L. cv. Panama) grown in deep flow technique in the tropics. ISHS Seed Symposium 504: VI Symposium on Stand Establishment. p. 135-146.

Krause, M.V. and L.K. Mahan. 1984. Minerals, p. 144-180. In: Krause, M.V. and L.K. Mahan (eds.). Food, nutrition, and diet therapy. 7th Ed W.B. Saunders Company, Philadelphia, PA.

Meacham, S., D. Grayscott, J.-J. Chen, and C. Bergman. 2008. Review of the dietary reference intake for calcium: Where do we go from here? Crit. Rev. Food Sci. Nutr. 48:378384.

Mou, B. 2005. Genetic variation of beta-carotene and lutein contents in lettuce. J. Amer. Soc. Hort. Sci. 130:870-876.

Mou, B. 2009. Nutrient content of lettuce and its improvement. Current Nutrition \& Food Science 5:242-248.

National Research Council. 1989. Diet and health: Implications for reducing chronic disease risk. Committee on Diet and Health, Food and
Nutrition Board. National Academy Press, Washington, DC.

Schlagnhaufer, B.E., E.J. Holcomb, and M.D. Orzolek. 1987. Effects of supplementary light, solution heating, and increased solution calcium levels on lettuce production in the nutrient film technique. Appl. Agr. Res. 2:124-129.

Steel, R.G.D. and J.H. Torrie. 1980. Principles and procedures of statistics: A biometrical approach. 2nd Ed. McGraw-Hill, New York, NY.

Sullivan, C. 2012. A closer look at nutrient density. 17 July 2013.<http://www.examiner.com/article/ a-closer-look-at-nutrient-density-3>.

Widodo, S.E., S. Shiraishi, and M. Shiraishi. 1996. On the interpretation of Brix value for the juice of acid citrus. J. Sci. Food Agr. 71:537-540. 